OPEN ACCESS

Edited by:

Marina G. Kalyuzhanaya, San Diego State University,

United States

Reviewed by:

Christopher Morton Thomas,

University of Birmingham,

United Kingdom

Timothy Meredith,

Pennsylvania State University,

United States

*Correspondence:

Emanuele Conte

Emanuele.Conte@glasgow.ac.uk

Sean D. Colloms

Sean.Colloms@glasgow.ac.uk

Specialty section:

This article was submitted to

Evolutionary and Genomic

Microbiology,

a section of the journal

Frontiers in Microbiology

Received: 26 November 2018

Accepted: 04 February 2019

Published: 27 February 2019

Citation:

Conte E, Mende L, Grainge I and

Colloms SD (2019) A Mini-ISY100

Transposon Delivery System Effective

in $\gamma$ Proteobacteria.

Front. Microbiol. 10:280.

doi: 10.3389/fmicb.2019.00280

\section{A Mini-ISY100 Transposon Delivery System Effective in $\gamma$ Proteobacteria}

\author{
Emanuele Conte ${ }^{1 *}$, Linda Mende ${ }^{2}$, lan Grainge ${ }^{2}$ and Sean D. Colloms ${ }^{1 *}$ \\ ${ }^{1}$ Institute of Molecular Cell and Systems Biology, University of Glasgow, Glasgow, United Kingdom, ${ }^{2}$ School \\ of Environmental and Life Sciences, University of Newcastle, Newcastle, NSW, Australia
}

Transposons are invaluable biological tools for the genetic manipulation of microorganisms. ISY100 from Synechocystis sp. PCC6803 is a member of the Tc1/mariner/IS630 superfamily, and is characterized by high transposition efficiency and a strong preference for TA target sequences. In this paper, we describe the design and application of a mini-ISY100 suicide vector for the in vivo creation of stable random transposon insertion libraries. The system was successfully applied in seven species belonging to four different orders of $\gamma$ proteobacteria. In all cases, delivery using conjugation consistently showed the highest transposition efficiency compared to chemical transformation or electroporation. We determined the frequency of transposon insertions in all the species and proved the utility of the system by identifying genes involved in colony coloration in Shewanella oneidensis. The ease and the efficiency of the protocol developed here allow the creation of complete knock-out libraries in an extensive range of host microorganisms in less than a week with no requirement for preparatory modification.

Keywords: ISY100, transposon mutagenesis, knock-out library, $\Phi \mathrm{C} 31$ integrase, cytochrome $c$

\section{INTRODUCTION}

Transposon insertion mutagenesis is a powerful technique to interrogate the entire genome of an organism, especially when other genetic manipulation tools are not available (van Opijnen and Camilli, 2013). The applications of this approach include the definition of essential genes (Akerley et al., 1998; Glass et al., 2006; Freed et al., 2016), determination of the underlying genetic causes of specific phenotypes (Rollefson et al., 2009; Ding and Tan, 2017) and the creation of complete non-redundant knock-out libraries for genetic studies in less-known species (Gallagher et al., 2013). All these studies take advantage of the ability of transposons to create a large pool of mutants by inserting at random sites, ideally covering the entire genome.

Transposons can also be used to insert a genetic cargo in the chromosomal DNA at random locations (Ehrmann et al., 1997), or to generate portable regions of homology that can act as substrate for other recombination enzymes to generate deletions or duplications (Hughes, 2007).

The majority of the transposon mutagenesis protocols described in the literature rely on members of the DD[E/D] family of transposases (Nesmelova and Hackett, 2010), which catalyze transposition via a cut-and-paste mechanism. Among these, derivatives of $\operatorname{Tn} 5, \operatorname{Tn} 7, \mathrm{Mu}, \operatorname{Tn} 10$, and Himar1 represent a common choice for the mutagenesis of prokaryotes (Choi and Kim, 2009; Picardeau, 2010), while at least ten transposons, including Sleeping Beauty, Himar1, and PiggyBac have been exploited for gene transfer applications in eukaryotes (Ni et al., 2008). The use of heterologous transposons has generally been preferred to avoid possible interference from related 
mobile elements in the host genome (Rubin et al., 1999). The complete lack of host requirements of mariner transposons of eukaryotic origin, like Himar 1, allows their routine use in bacteria (Rubin et al., 1999), while in some cases transposons of bacterial origin (e.g., Tn5) have been used to mutagenize eukaryotic organisms with complete functionality (Suganuma et al., 2005).

Although lack of insertion site preference is desirable for mutagenesis experiments, all transposons display a certain degree of target site selectivity, and none of them can be truly defined as "random" (Liu et al., 2005). Target site preferences vary for different transposons and can be guided by requirement for a specific sequence (Wolkow et al., 1996), by the transcriptional status of a genomic region (Fraser et al., 1996) or by topological factors like the bending of the DNA in GC rich sequences (Green et al., 2012). These deviations from the assumed randomness can influence the result of an experiment, and limit coverage of the library (Kimura et al., 2016). The use of different transposons in the same species can lead to different and complementary results (Jacobs et al., 2003; Liberati et al., 2006). Furthermore, a particular transposon system could have a limited efficiency or not work at all in a species of interest (Bouhenni et al., 2005), or show an insertion site preference in a specific host (Bardarov et al., 1997), creating the need for an alternative method. It is, therefore, desirable to have multiple options to choose from. To expand the range of tools available for the genetic manipulation of different organisms, we set up a system relying on the use of the ISY100 (ISTcSA) transposon from Synechocystis sp. PCC6803 (Feng and Colloms, 2007).

ISY100 transposon is a member of the Tc1/mariner/IS630 family with a size of $947 \mathrm{bp}$ and a single open reading frame coding for its own transposase (Urasaki et al., 2002). The transposase from ISY100 recognizes two 24 bp imperfect inverted repeats at the transposon ends, and has a marked preference for TA insertion sites (Feng and Colloms, 2007). ISY100 was isolated from the chromosome of Synechocystis sp. PCC6803, where it is present in 20 copies (Cassier-Chauvat et al., 1997; Urasaki et al., 2002). Its cut-and-paste reaction mechanism was studied both in vivo (Urasaki et al., 2002) and in vitro (Feng and Colloms, 2007), and showed a high transposition efficiency into the chromosome of Escherichia coli (Urasaki et al., 2002). To take advantage of these qualities, we designed a mini-ISY100 delivery system based on a R6K suicide vector and compared the efficiency of different delivery methods. Mini ISY100 transposition was tested in multiple strains of $E$. coli and in six other species of $\gamma$ proteobacteria, producing insertion libraries that could be screened for mutant phenotypes.

\section{MATERIALS AND METHODS}

\section{Bacterial Strains}

A list of the bacterial strains used in this study is shown in Table 1. All species were grown in LB medium (Sambrook and Russell, 2001), supplemented when necessary with $0.3 \mathrm{mM}$ thymidine, $0.3 \mathrm{mM}$ 2,6-diaminopimelic acid (DAP), chloramphenicol $(25 \mu \mathrm{g} / \mathrm{ml})$ or kanamycin $(50 \mu \mathrm{g} / \mathrm{ml}$ for all; except for Pseudomonas aeruginosa $300 \mu \mathrm{g} / \mathrm{ml}$ ). Solid
TABLE 1 | Bacterial strains used in this study.

\begin{tabular}{|c|c|c|}
\hline Bacterial strain & Genotype & $\begin{array}{l}\text { Source or } \\
\text { reference }\end{array}$ \\
\hline E. coli DH5 $\alpha$ & $\begin{array}{l}\left(\mathrm{F}^{-}\right) \text {supE44 } \Delta(\mathrm{lac}) \cup 169 \\
(\varphi 80 \mathrm{lac} Z \Delta M 15) \Delta(\arg F) \\
\text { hsdR17 recA1 endA1 gyrA96 } \\
\text { thi-1 relA1 }\end{array}$ & Taylor et al., 1993 \\
\hline E. coli TOP10 & $\begin{array}{l}\left(\mathrm{F}^{-}\right) \text {mcrA } \\
\Delta(\mathrm{mrr}-\mathrm{hsdRMS}-\mathrm{mcrBC}) \\
\varphi 80 l a c Z \Delta M 15 \Delta(\mathrm{lac}) X 74 \text { nupG } \\
\text { recA1 araD139 } \Delta(\text { ara-leu }) 7697 \\
\text { galE15 galK16 rpsL(StrR) } \\
\text { endA1 } \lambda^{-}\end{array}$ & $\begin{array}{l}\text { (Invitrogen) } \\
\text { Presumed identical } \\
\text { to DH10B (Grant } \\
\text { et al., 1990) }\end{array}$ \\
\hline E. coli MG1655 & $\mathrm{K}-12 \mathrm{~F}^{-} \lambda^{-}$ilvG rfb-50 rph-1 & Bachmann, 1996 \\
\hline E. coli $\pi 3$ & $\begin{array}{l}\text { TG1 }\left(\mathrm{F}^{-}\right) \Delta \text { thyA::(erm-pir116) } \\
{[E m R]}\end{array}$ & $\begin{array}{l}\text { Demarre et al., } \\
2005\end{array}$ \\
\hline E. coli MFDpir & 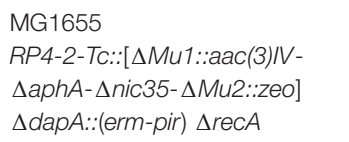 & $\begin{array}{l}\text { Ferrières et al., } \\
2010\end{array}$ \\
\hline S. oneidensis MR-1 & Wild-type & $\begin{array}{l}\text { Venkateswaran } \\
\text { et al., } 1999\end{array}$ \\
\hline P. ananatis & Wild-type & $\begin{array}{l}\text { DSMZ collection } \\
\text { No.30071 }\end{array}$ \\
\hline $\begin{array}{l}\text { P. fluorescens } \\
\text { SBW25 }\end{array}$ & Wild-type & $\begin{array}{l}\text { Rainey and Bailey, } \\
1996\end{array}$ \\
\hline $\begin{array}{l}\text { A. baumannii } \\
\text { ATCC19606 }\end{array}$ & Wild-type & $\begin{array}{l}\text { Bouvet and } \\
\text { Grimont, } 1986\end{array}$ \\
\hline A. baylyi ADP1 & Wild-type & $\begin{array}{l}\text { Metzgar et al., } \\
2004\end{array}$ \\
\hline$P$. aeruginosa PAO1 & Wild-type & Holloway, 1975 \\
\hline
\end{tabular}

medium was obtained by adding $15 \mathrm{~g} / \mathrm{l}$ of agar. Bacteria were incubated at $37^{\circ} \mathrm{C}$ (Escherichia coli, Acinetobacter baumannii, Acinetobacter baylyi, and Pseudomonas aeruginosa) or $30^{\circ} \mathrm{C}$ (Shewanella oneidensis, Pantoea ananatis and Pseudomonas fluorescens).

\section{pISY100mini Plasmid Construction}

The pISY100mini suicide plasmid was created by inserting a synthetic DNA sequence into the R6K $\gamma$ origin plasmid pSW23T (Demarre et al., 2005) between the SalI and the SacI restriction sites. The inserted DNA sequence includes ISY100 inverted repeats IRL and IRR flanking the aminoglycoside phosphotransferase gene (kanamycin resistance, $\mathrm{Kan}^{\mathrm{R}}$ ) from $\mathrm{Tn} 5$ (Beck et al., 1982), forming the mini-ISY100 transposon, followed by the T7 g10-L ribosome binding site (Olins and Rangwala, 1989) and the ISY100 transposase gene (Feng and Colloms, 2007). The pISY100mini-LP plasmid contained a $\Phi C 31$ integrase-based "landing pad" in pISY100mini, and was constructed by inserting synthetic DNA sequences containing a $\Phi C 31$ attB ${ }^{\mathrm{TT}}$ site (GTGCCAGGGCGTGCCCTTGGGCTCCCCGGGCGCG) and the counter-selectable E. coli rpsL gene between the AatII and BsaI sites of pISY100mini, and a fragment containing an $a t t B^{\mathrm{TC}}$ site (GTGCCAGGGCGTGCCCTCGGGCTCCCCGGGCGCG), in the opposite orientation, between the NheI and the SpeI sites. Replication of these ISY100 donor plasmids requires the pir gene, therefore both plasmids were maintained in 
E. coli $\pi 3$ (Demarre et al., 2005). All plasmids were verified by DNA sequencing.

\section{Chemical Transformation and Electroporation}

Suicide plasmids were introduced into bacteria using chemical transformation or electroporation. Chemical transformation of $E$. coli, $P$. ananatis, $P$. fluorescens, $S$. oneidensis used a standard heat-shock protocol with calcium chloride treated cells (Sambrook and Russell, 2001). To prepare electro-competent cells, $200 \mathrm{ml}$ of exponentially growing culture $(\mathrm{OD} 600=0.4)$ was centrifuged for $7 \mathrm{~min}$ at $8000 \mathrm{~g}$ then resuspended in $100 \mathrm{ml}$ pre-chilled $10 \%$ glycerol. Centrifugation was repeated three more times with cells resuspended first in $50 \mathrm{ml}$ and then in $25 \mathrm{ml}$ of $10 \%$ glycerol, before final resuspension in $500 \mu \mathrm{l}$ of $10 \%$ glycerol. Electroporation was performed in $0.2 \mathrm{~cm}$ cuvettes at $2.5 \mathrm{kV}(0.55 \mathrm{kV}$ for $S$. oneidensis $)$ using $40 \mu \mathrm{l}$ of cells mixed with $165 \mathrm{ng}$ of plasmid DNA. After electroporation, $1 \mathrm{ml}$ of LB (with thymidine for $\pi 3$ ) was added and cells were incubated with shaking for $1.5 \mathrm{~h}$ at $37^{\circ} \mathrm{C}$ or $30^{\circ} \mathrm{C}$ as appropriate. After this, an aliquot of cells was spread on selective plates. All the experiments were repeated in triplicate, and results reported as mean \pm standard deviation.

\section{Conjugation}

The donor strain for the conjugation experiments was obtained by introducing pISY100mini or pISY100mini-LP into E. coli MFDpir (Ferrières et al., 2010) by chemical transformation. Overnight cultures of donor and recipient strains $(1 \mathrm{ml}$ each) were pelleted by centrifugation $(3000 \mathrm{~g}-5 \mathrm{~min})$ and washed twice in $500 \mu \mathrm{l}$ of dilution buffer $(10 \mathrm{mM}$ Tris $\mathrm{pH}$ 7.5, $10 \mathrm{mM}$ $\mathrm{MgSO}_{4}, 68 \mathrm{mM} \mathrm{NaCl}_{2}$ ) before final resuspension in $500 \mu \mathrm{l}$ of dilution buffer. The donor strain $(100 \mu \mathrm{l})$ was mixed gently with $50 \mu \mathrm{l}$ of the recipient cells ( $100 \mu \mathrm{l}$ for E. coli) by pipetting up and down. The mixture was pipetted without spreading at the center of a $\mathrm{LB} / \mathrm{DAP}$ agar plate and incubated at $30^{\circ} \mathrm{C}$ for $5 \mathrm{~h}$ (A. baylyi, A. baumannii, and $P$. aeruginosa), $8 \mathrm{~h}$ (E. coli and S. oneidensis) or overnight ( $16 \mathrm{~h} ; P$. ananatis, $P$. fluorescens). Cells were washed off the plate with $3 \mathrm{ml}$ of $\mathrm{LB}(700 \mu \mathrm{l}$ for the experiments conducted with pISY100-LP-mini) and serial dilutions were spread on plates containing kanamycin and no DAP, and incubated at 30 or $37^{\circ} \mathrm{C}$ for $48 \mathrm{~h}$ to select for recipient cells containing a mini-ISY 100 transposon inserted into the chromosome. Each experiment was repeated independently three times to determine the mean and standard deviation.

\section{Arbitrary PCR}

The protocol for colony arbitrary PCR was adapted from Das et al. (2005) using the primers KanR_3 GACCGCTTCCTCGTGCTTTAC, KanR_4 TCTATCGCCTTC TTGACGAGTTC, Arb1 GGCCACGCGTCGACTAGTCANN NNNNNNNNGATAT, and Arb2 GGCCACGCGTCGACTA GTCA. A single colony was picked from a plate, resuspended in $50 \mu \mathrm{l}$ of distilled water and heated at $95^{\circ} \mathrm{C}$ for $15 \mathrm{~min}$. An aliquot of this suspension $(5 \mu \mathrm{l})$ was added to a PCR mixture containing $25 \mu \mathrm{l}$ Taq 2X Master Mix (New England BioLabs), $2.5 \mu l$ each of

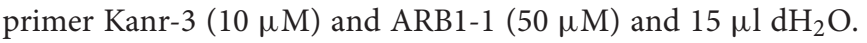
This was subjected to an initial denaturation at $95^{\circ} \mathrm{C}$ for $5 \mathrm{~min}$, followed by 6 cycles of $95^{\circ} \mathrm{C}-30 \mathrm{~s}, 30^{\circ} \mathrm{C}-30 \mathrm{~s}, 72^{\circ} \mathrm{C}-1.5 \mathrm{~min}$, and then 30 cycles of $95^{\circ} \mathrm{C}-30 \mathrm{~s}, 45^{\circ} \mathrm{C}-30 \mathrm{~s}, 72^{\circ} \mathrm{C}-2 \mathrm{~min}$, with a final elongation at $72^{\circ} \mathrm{C}$ for $4 \mathrm{~min}$. Five microliter of this PCR product was used as DNA template in a second PCR mixture containing $25 \mu \mathrm{l}$ Taq $2 \mathrm{X}$ Master Mix (New England BioLabs), $2.5 \mu \mathrm{l}$ each of primer Kanr-4 and Arb2 (10 $\mu \mathrm{M}$ each)

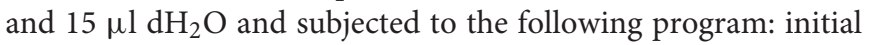
denaturation $95^{\circ} \mathrm{C}-5 \mathrm{~min}$, then 30 cylcles of $95^{\circ} \mathrm{C}-30 \mathrm{~s}, 52^{\circ} \mathrm{C}-$ $30 \mathrm{~s}, 72^{\circ} \mathrm{C}-2 \mathrm{~min}$, followed by $72^{\circ} \mathrm{C}-4 \mathrm{~min}$. The PCR products were purified using a Qiagen PCR cleanup kit and $15 \mu$ l of each reaction was sequenced with primer Kanr-4.

\section{Estimation of the Mutant Library Coverage}

The completeness of a transposon insertion mutant library can be predicted by assuming a Poisson distribution for the frequency of the transposon insertions in the genome (Baym et al., 2016). Essential genes will not be represented in the library, and are excluded from the calculations. Assuming a genome with $\mathrm{N}$ non-essential genes, all with an equal probability of insertion, any single gene will be targeted by the transposase with a probability of:

$$
P(x, k, N)=e^{-k / N}\left(\frac{k}{N}\right)^{x}\left(\frac{1}{x !}\right)
$$

Where $\mathrm{x}$ represents the number of insertions in the gene and $\mathrm{k}$ the number of mutants in the collection. From this, the probability of no insertion in any given gene is:

$$
P(0, k, N)=e^{-k / N}
$$

Meaning that the total number of genes that will not have any insertions is:

$$
n_{\text {no insertions }}=N e^{-k / N}
$$

By complementarity, the total number of genes that will have at least one transposon insertion is:

$$
n_{\text {insertions }}=N\left(1-e^{-k / N}\right)
$$

To estimate the number of essential genes, we referred to the empirically determined relationship of Gao et al. (2015). According to this, the percentage of essential genes $y$ in a bacterium decays exponentially in relation to the length $\mathrm{x}$ of the genome following the equation:

$$
y=144 e^{-x / 719649}+12
$$

The information on the size of the genome and the number of genes for the analyzed bacteria was derived from the KEGG database ${ }^{1}$.

\footnotetext{
${ }^{1}$ http://www.genome.jp/kegg/kegg2.html
} 


\section{RESULTS}

\section{Plasmid Design}

The aim of this work was to design and test a suicide plasmid for the delivery of ISY100 mini-transposon insertions to the genomes of a variety of bacterial species. The suicide plasmid (pISY100mini; Figure 1A) contains a mini transposon (mini-ISY100), consisting of the Tn5 aminoglycoside phosphotransferase gene $\left(\operatorname{Kan}^{\mathrm{R}}\right)$ between ISY100 inverted repeat sequences (IRL and IRR), and has an R6K $\gamma$ origin of replication. Replication of pISY100mini is strictly dependent on the R6K pir-encoded $\Pi$ protein, which is not encoded on the plasmid but can be provided in trans allowing replication in pir $^{+}$host strains. ISY100 transposase is encoded on pISY100mini outside the mini-ISY100 transposon. After introducing pISY100mini into a pir $^{-}$recipient strain, the plasmid cannot replicate, and

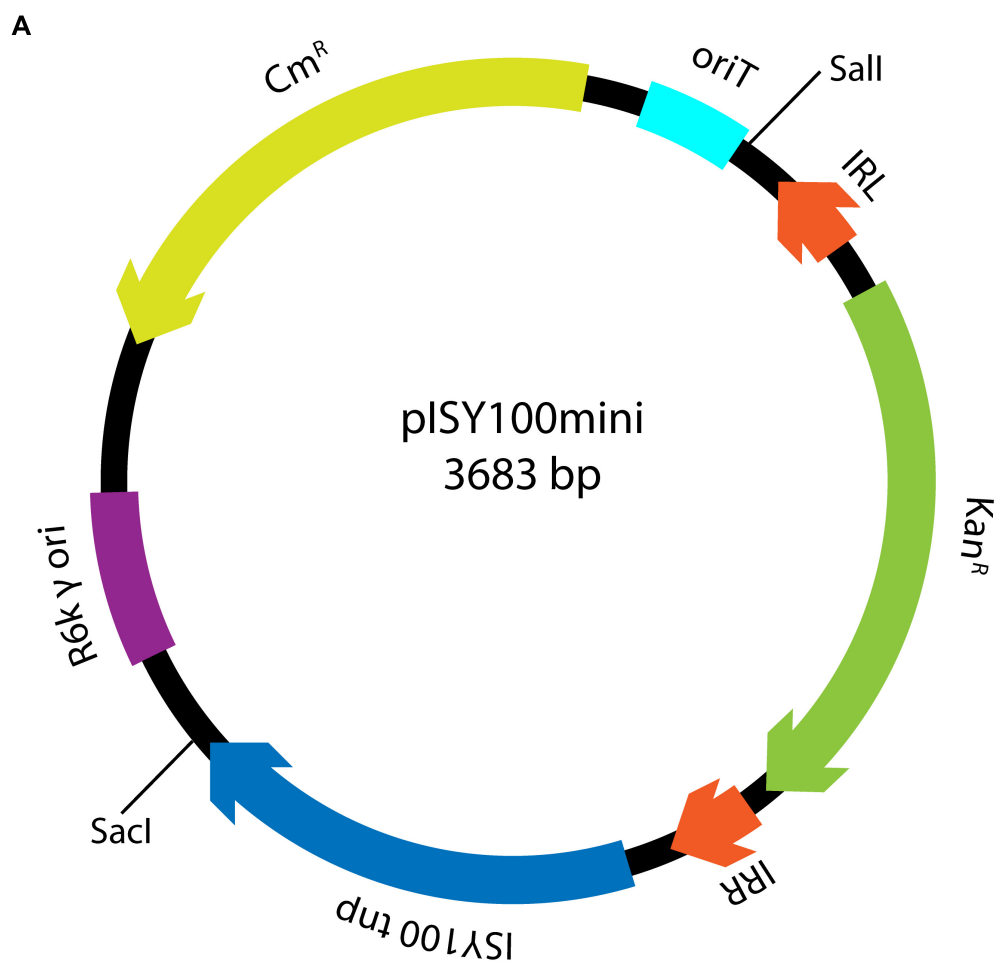

B

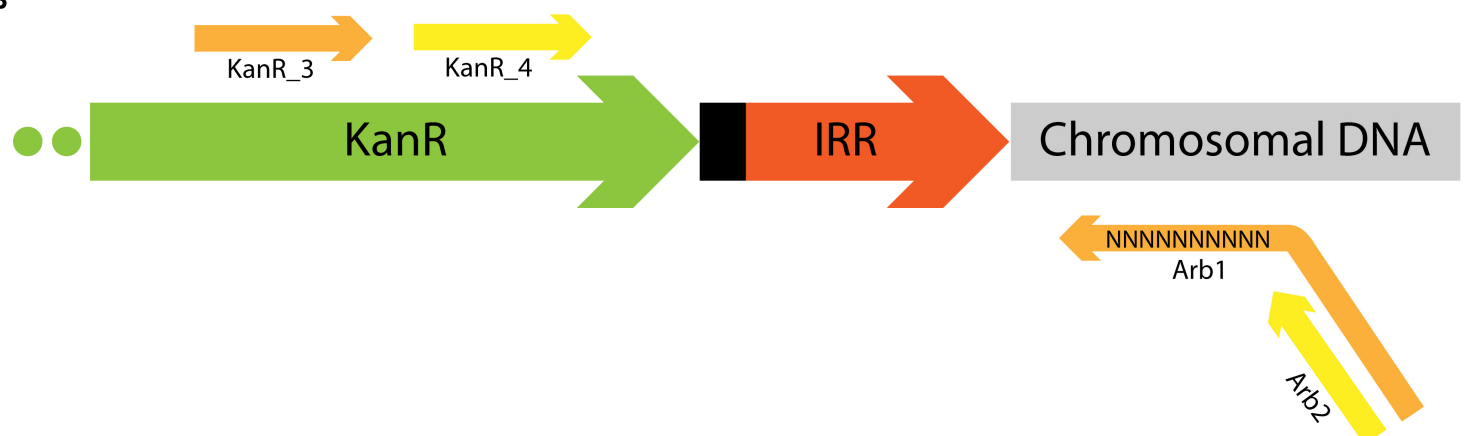

FIGURE 1 | Mini-ISY100 delivery system. (A) Map of the pISY100mini suicide vector, including the R6K $\gamma$ origin of replication (purple), the origin of transfer oriT (light blue), the chloramphenicol resistance gene (yellow), the ISY100 transposase gene (blue), the ISY100 inverted repeat sequences IRL and IRR (dark orange) and the kanamycin resistance gene (green). (B) mini-ISY100 inserted in the host chromosome. The primers used in the arbitrary PCR to identify the mini-ISY100 transposon insertion site in the chromosomal DNA (light gray) are represented in orange (KanR_3 and Arb1, first amplification step) or yellow (KanR_4 and Arb2, second amplification step). 
kanamycin resistant colonies will arise only if the mini-ISY100 transposes to the chromosome. Insertions should be stable as the transposase gene is left behind on the non-replicating donor plasmid. pISY100mini carries a gene conferring resistance to chloramphenicol $\left(\mathrm{Cm}^{\mathrm{R}}\right)$ outside the mini-ISY100 so that colonies arising from transposition should be kanamycin resistant but chloramphenicol sensitive.

The suicide plasmid could be delivered to recipient cells by transformation, however, conjugation might be a more efficient delivery system. An IncP origin of transfer (oriT) was therefore included on the pISY100mini backbone to allow mobilization of pISY100mini using the RP4 conjugative machinery.

\section{Transposition in E. coli}

To test the function and the efficiency of our mini-ISY100 delivery system, transposition was assayed in two commonly used (pir ${ }^{-}$) strains of E. coli: DH5 $\alpha$ and TOP10. The pISY100mini suicide plasmid was introduced into these strains using a simple chemical transformation protocol. No colonies were obtained when samples were spread on plates containing chloramphenicol, confirming that the suicide plasmid cannot replicate in these host strains. The number of cells in which transposition had taken place was determined by counting the number of colonies on LB plates containing kanamycin. This number ranged from an average of 18 per transformation for $\mathrm{DH} 5 \alpha$, to about 120 for TOP10 (Table 2). The total number of cells surviving the transposition procedure was determined by plating on non-selective plates, and the transposition frequency was then calculated by dividing the number of kanamycin resistant colonies by the total number of colony forming units (Table 2). The results show that approximately 1 in 800,000 (DH5 $\alpha$ ) to 1 in 280,000 (TOP10) cells in the transformation undergo transposition onto their chromosome.

Production of a transposon insertion by transformation with pISY100mini requires two successful steps: delivery of DNA into the cell, followed by transposition from the suicide plasmid to the host genome. To separate these two different events, we defined the transposition "activity" (Table 2) as the ratio between the transposition frequency of PISY100mini, depending on both transposition and DNA uptake, and the transformation frequency of the cells which depends just on delivery of the DNA. The transformation efficiency cannot be measured in $\mathrm{DH} 5 \alpha$ and
TOP10 using pISY100mini, as this plasmid cannot replicate in these cells. Instead, the efficiency of DNA delivery by chemical transformation was measured for each batch of competent cells, using the plasmid pUC71K (Taylor and Rose, 1988). This plasmid is comparable in size to pISY100mini and carries the same $\operatorname{Kan}^{\mathrm{R}}$ gene, but can be maintained in a pir ${ }^{-}$host due to its pMB1/ColE1 origin of replication. The results indicate that after chemical transformation, in the order of 1 in 1000 cells takes up plasmid DNA, and of these about 1 in 1000 has a transposition event to the chromosome (Table 2).

To increase the transformation frequency, electroporation was then tested to deliver pISY100mini for transposition. In these experiments, the transformation frequency increased, but the transposition activity decreased, so that the overall transposition frequency was similar to that obtained with chemical transformation (Table 2). Because of the large number of cells used in the electroporation reactions, significantly more transposition events were obtained by electroporation than by chemical transformation; $\sim 2000$ colonies were obtained by electroporation with both $\mathrm{DH} 5 \alpha$ and TOP10 (Table 2). Thus, a library large enough to have nearly full coverage of all non-essential genes in $E$. coli (requiring $\sim 12,000$ insertions mutants) could be produced by combining colonies from several electroporation reactions.

Conjugation is a highly efficient method of delivering plasmid DNA to bacterial cells, so we tested it as an alternative delivery method for pISY100mini. The suicide plasmid pISY100mini was introduced into E. coli MFDpir (Ferrières et al., 2010) by chemical transformation. This strain expresses the pir gene for replication of pISY100mini and the RP4 conjugative proteins, allowing mobilization of pISY100mini. MFDpir also contains a mutation in the dapA gene, allowing easy counterselection after conjugation using media lacking diaminopimelic acid (DAP).

A plate-based mating reaction was set up between the MFDpir pISY100mini donor strain and the two different recipient strains, $\mathrm{DH} 5 \alpha$ and TOP10, as described in the Materials and Methods section. After $8 \mathrm{~h}$ of co-incubation of donor and recipient strains on LB DAP plates, cells were washed off and dilutions were plated on different media. No colonies were obtained on LB Cm plates, confirming that pISY100mini cannot replicate in the recipients, and that there is no reversion of the $\operatorname{dapA}$ mutation in the donor. LB plates lacking DAP were used to

TABLE 2 | Delivery of the mini-ISY100 transposon in E. coli via chemical transformation and electroporation.

\begin{tabular}{|c|c|c|c|c|}
\hline \multirow[b]{2}{*}{ Strain } & \multicolumn{2}{|c|}{ pISY100mini } & \multirow{2}{*}{$\begin{array}{c}\text { pUC71K (control) } \\
\text { Transformation frequency }^{\mathrm{b}}\end{array}$} & \multirow[b]{2}{*}{ Mini-ISY100 activity ${ }^{c}$} \\
\hline & $\operatorname{Kan}^{\mathrm{R}}$ colonies/reaction ${ }^{\mathrm{a}}$ & Transposition frequency $^{\mathbf{b}}$ & & \\
\hline $\mathrm{DH} 5 \alpha$ & $17.5 \pm 3.54$ & $1.29 \times 10^{-6} \pm 2.95 \times 10^{-7}$ & $1.40 \times 10^{-3} \pm 2.71 \times 10^{-4}$ & $9.21 \times 10^{-4} \pm 2.76 \times 10^{-4}$ \\
\hline TOP10 & $117 \pm 28.9$ & $3.57 \times 10^{-6} \pm 9.47 \times 10^{-7}$ & $7.32 \times 10^{-3} \pm 7.43 \times 10^{-4}$ & $4.88 \times 10^{-4} \pm 1.39 \times 10^{-4}$ \\
\hline \multicolumn{5}{|c|}{ Electroporation } \\
\hline
\end{tabular}

${ }^{a}$ Number of $K^{2}{ }^{R}$ colonies obtained from a single reaction. ${ }^{b}$ Number of colonies on LB/Kan divided by the number of colonies on LB. ${ }^{c}$ Transposition frequency divided by transformation frequency. 
count the total number of recipient cells, while LB lacking DAP but containing kanamycin was used to select for transposition events in DH5 $\alpha$ or TOP10. Libraries of $10^{5}$ transposon insertion mutants were routinely obtained from each conjugation reaction (Table 3), although it should be noted that due to the extended incubation times during the conjugation, these colonies probably do not all represent independent transposition events. The transposition frequency after conjugation, $\sim 10^{-2}-10^{-3}$, calculated as the proportion of recipient cells that became kanamycin resistant, was significantly higher than obtained by transformation, $\sim 10^{-5}-10^{-6}$ (compare Tables 2, 3).

The conjugation frequency of pISY100mini from MFDpir was measured by mating MFDpir/pISY100mini with the pir ${ }^{+}$ E. coli strain $\pi 3$, allowing replication of pISY100mini in the recipient. Cells were plated on $\mathrm{LB}$, to count the total number of recipient cells, and $\mathrm{LB} / \mathrm{Kan}+\mathrm{Cm}$, to determine the number of transconjugants, giving a conjugation frequency of $\sim 4 \times 10^{-2}$. The transposition activity of the mini-ISY100 transposon after conjugation in the E. coli pir- strains was then estimated by dividing the transposition frequency by the conjugation frequency of pISY100mini from MFDpir to $\pi 3$ (Table 3). These calculations indicate that a substantial proportion of cells that receive pISY100mini by conjugation (as high as $40 \%$ for $\mathrm{DH} 5 \alpha$ ) undergo transposition from pISY100mini to the host chromosome.

\section{Creation of Knock-Out Libraries in $\gamma$ Proteobacteria}

To show that pISY100mini can be used to create transposon insertion libraries in other bacterial species, we tested transposition in S. oneidensis, $P$. ananatis, and $P$. fluorescens. These species have all shown biotechnological potential (Fredrickson et al., 2008; Silby et al., 2009; Hara et al., 2012), and are representatives of three different orders of $\gamma$ proteobacteria. Our first attempts to deliver pISY100mini in these species using chemical transformation and electroporation were unsuccessful, producing no $\mathrm{Kan}^{\mathrm{R}}$ colonies. Therefore, we attempted to deliver pISY100mini by inter-species conjugation, using E. coli MFDpir/pISY100mini as donor. Conjugation was conducted on LB DAP plates by mixing donor and recipient strains as described in the Materials and Methods section, and leaving them to incubate at $30^{\circ} \mathrm{C}$ for $8-16 \mathrm{~h}$. No colonies were obtained when the conjugations were plated on LB Cm plates, demonstrating that PISY100mini cannot replicate in any of these species, and controls with individual parental strains produced no colonies on LB Kan plates. Conjugation between MFDpir/pISY100mini and the different recipient species yielded from $10^{3}$ to $10^{5} \mathrm{Kan}^{\mathrm{R}}$ colonies, depending on the recipient species. Transposition frequencies (the fraction of recipient cells that had become $\mathrm{Kan}^{\mathrm{R}}$ ) were in the order of $10^{-6}$ for P. fluorescens, $10^{-5}$ for $P$. ananatis and $10^{-4}$ for S. oneidensis (Table 4).

To confirm that the observed $\mathrm{Kan}^{\mathrm{R}}$ colonies were due to mini-ISY100 transposon insertions in the recipient host genome, arbitrary PCR was used to amplify the DNA flanking transposon insertion sites (Das et al., 2005). Five $\mathrm{Kan}^{\mathrm{R}}$ colonies produced by conjugation of MFDpir/pISY100mini with each species were randomly selected and subjected to colony PCR using a forward primer specific for the kanamycin resistance gene and a reverse “arbitrary" primer containing a 10 bp random sequence at its $3^{\prime}$ end. The products of this reaction were further amplified by PCR using a nested primer from the kanamycin resistance gene and a reverse primer matching a fixed region from the $5^{\prime}$ end of the degenerate primer (Figure 1B). PCR products were sequenced by dideoxy sequencing using a primer from the kanamycin resistance gene, allowing unique determination of the miniISY100 transposon insertion site (Supplementary Table S1). All the transposon insertions could be identified in the genomic sequence of the target organism and were at TA dinucleotides, as expected for ISY100.

To create a useful insertional knock-out library in the species studied, the library should be large enough for nearly full coverage of the genome. A practical target to aim for is for $>95 \%$ of non-essential genes to have at least one insertion. From the Poisson distribution (see the Materials and Methods section), this requires approximately $3 \mathrm{~N}$ insertions, where $\mathrm{N}$ is the number of non-essential genes in the genome. The number of non-essential genes has been determined for $S$. oneidensis as $\mathrm{N}_{\text {oneidensis }} \cong 3700$ genes (Baym et al., 2016), and can be estimated from the annotated genome sequences of $P$. ananatis (Hara et al., 2012) and P. fluorescens (Silby et al., 2009). $P$. ananatis has a genome of $4.88 \mathrm{Mbp}$, with 4067 proteincoding genes, while $P$. fluorescens has a genome of $6.72 \mathrm{Mbp}$, with 5921 protein-coding genes. Based on their genome sizes,

TABLE 4 | mini-ISY100 transposition frequency in different species.

\begin{tabular}{lll}
\hline $\begin{array}{l}\text { Recipient } \\
\text { strain }\end{array}$ & Kan $^{\mathbf{R}}$ colonies/reaction & Transposition frequency \\
\hline S. oneidensis & $1.94 \times 10^{5} \pm 2.38 \times 10^{4}$ & $2.48 \times 10^{-4} \pm 1.42 \times 10^{-4}$ \\
P. ananatis & $2.18 \times 10^{4} \pm 1.87 \times 10^{3}$ & $1.04 \times 10^{-5} \pm 1.4 \times 10^{-6}$ \\
P. fluorescens & $7.04 \times 10^{3} \pm 3.80 \times 10^{2}$ & $1.80 \times 10^{-6} \pm 6.14 \times 10^{-7}$ \\
\hline
\end{tabular}

${ }^{a}$ Total number of $\mathrm{Kan}^{R}$ colonies obtained from a single plate mating between MFDpir and the indicated recipient bacteria, calculated from plating appropriate dilutions. ${ }^{b}$ Number of colonies on LB/Kan divided by the number of colonies on LB.

TABLE 3 | mini-ISY100 transposon activity in E. coli after conjugation.

\begin{tabular}{|c|c|c|c|}
\hline Strain & $\mathrm{Kan}^{\mathrm{R}}$ colonies/reaction $^{\mathrm{a}}$ & Transposition frequency ${ }^{b}$ & Mini-ISY100 activityc \\
\hline $\mathrm{DH} 5 \alpha$ & $1.05 \times 10^{5} \pm 2.12 \times 10^{4}$ & $1.54 \times 10^{-2} \pm 8.25 \times 10^{-3}$ & $4.20 \times 10^{-1} \pm 3.70 \times 10^{-1}$ \\
\hline TOP10 & $3.50 \times 10^{5} \pm 1.71 \times 10^{5}$ & $1.75 \times 10^{-3} \pm 9.71 \times 10^{-4}$ & $4.78 \times 10^{-2} \pm 4.26 \times 10^{-2}$ \\
\hline
\end{tabular}

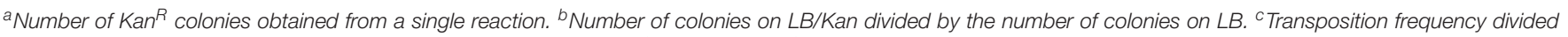
by frequency of conjugation using $E$. coli $\pi 3$ as recipient $\left(3.66 \times 10^{-2} \pm 2.55 \times 10^{-2}\right)$. 

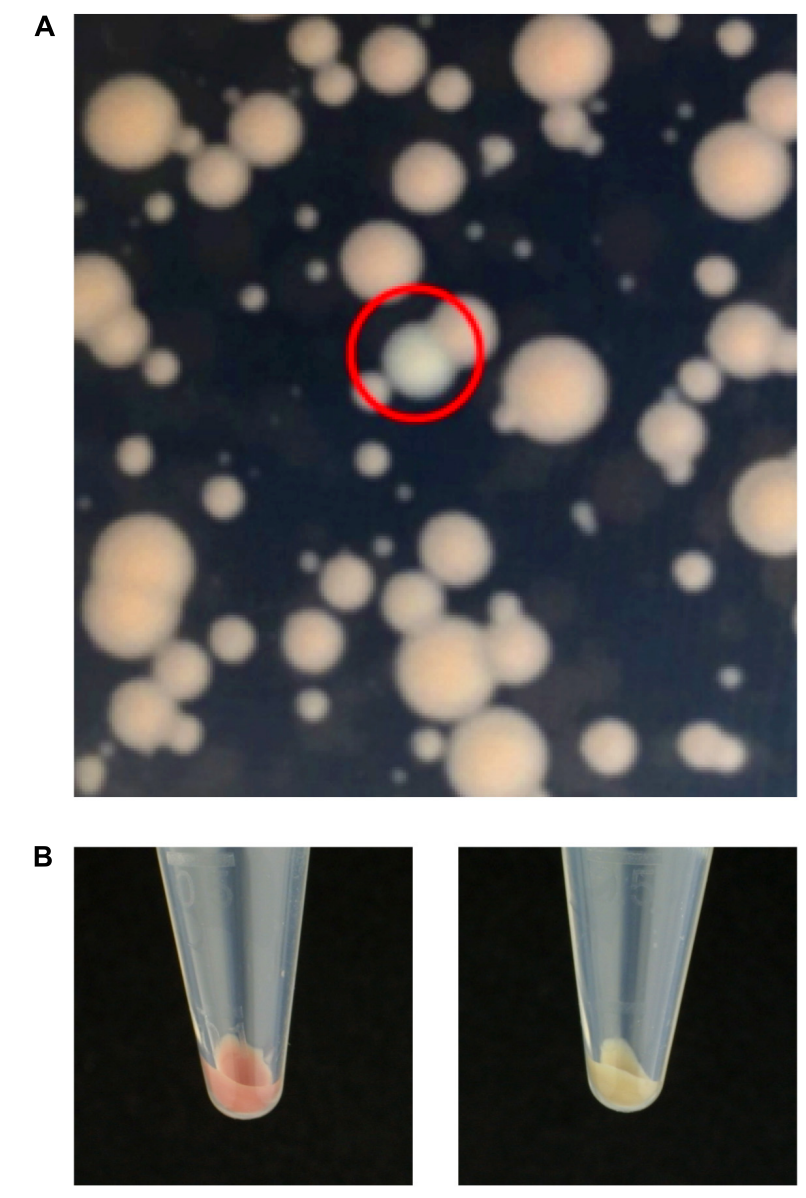

FIGURE 2 | Genetic screen for genes involved in S. oneidensis colony color. A mini-ISY100 insertion library was generated and plated on LB/Kan to screen for mutants that had lost the red-brown coloration. (A) Close-up of kanamycin resistant $S$. oneidensis colonies obtained after conjugation with

MFDpir/pISY100mini. Heterogeneity in colony size might be due to fitness differences caused by transposon insertions. Alternatively, small colonies might reflect late (post-plating) transposition events. A mutant with pale colony color is circled in red. (B) Pellets obtained after centrifuging $2.8 \mathrm{ml}$ LB liquid cultures $\left(30^{\circ} \mathrm{C}\right.$, overnight) showing the difference in color between the wild-type $S$. oneidensis (left) and a pale mutant (right). about $12 \%$ of these genes are expected to be essential (Gao et al., 2015) resulting in $\mathrm{N}_{\text {ananatis }} \cong 3600$ and $\mathrm{N}_{\text {fluorescens }} \cong 5200$. Thus, libraries ranging from 12,000 to 16,000 mutants are required for $95 \%$ genomic coverage of $S$. oneidensis, $P$. ananatis and P. fluorescens. Therefore, the numbers of mini-ISY100 transposition events obtained with our delivery system are sufficient to create knock-out libraries with 95\% coverage in $S$. oneidensis and $P$. ananatis in a single experiment, while two independent conjugation reactions of this scale would be required for $P$. fluorescens (Table 4).

\section{Identification of Genes Involved in Colony Color in Shewanella oneidensis}

Having proved the efficiency of transposition using pISY100mini, we wished to demonstrate the utility of ISY100 for genetic screens. S. oneidensis produces colonies with a pale brown coloration on LB agar plates and we decided to screen for mutations in genes required for this colony color. A library of $S$. oneidensis mutants was created by mating MFDpir/pISY100mini with S. oneidensis and selecting on LB Kan plates. From a library of approximately 12,000 mutants, four white colonies were identified (Figure 2) and streaked to single colonies. Arbitrary PCR was used to amplify the DNA flanking the mini-ISY100 insertions in these mutants, and the insertion site was determined by DNA sequencing. Three of the mutants had insertions in the $c c m F$ gene of $S$. oneidensis, at three different locations within this gene, while the fourth colony had an insertion in the $d s b D$ gene (Table 5). The product of $c \mathrm{~cm} F$, a cytochrome $c$ maturation protein, has a role in the reduction of heme for its transfer to the apocytochrome $c$ (Verissimo and Daldal, 2014). The $d s b D$ gene encodes a membrane protein belonging to the thioredoxin family, whose function in bacteria is to maintain apocytochrome $c$ in a reduced form by acting on the assembly protein CcmG (Verissimo and Daldal, 2014). Both of these proteins are therefore involved in the biogenesis and maturation of cytochrome $c$, indicating that a defect in this pathway might underlie the observed pale colony color phenotype. Indeed, a pale colony phenotype has previously been observed for mutants in $c c m F$ in S. oneidensis (Fu et al., 2015). A causal relationship between the mini-ISY100 insertion in $d s b D$

TABLE 5 | Genome insertion sites of the mini-ISY100 in S. oneidensis pale colored colonies.

\begin{tabular}{|c|c|c|c|c|}
\hline Mutant ID & Sequence $^{a}$ & Locus tag & Gene product & $\begin{array}{c}\text { Genome } \\
\text { insertion site }\end{array}$ \\
\hline \multicolumn{5}{|c|}{ Shewanella oneidensis - NCBI: NC_004347.2 } \\
\hline So_pale-1 & $\begin{array}{l}\text { (mini-ISY100)TACTAATCGGA } \\
\text { TCGCC (plus/minus) }\end{array}$ & SO_0266 & $\begin{array}{l}\text { Cytochrome c-type biogenesis } \\
\text { protein CcmF }\end{array}$ & 267,474 \\
\hline So_pale-2 & $\begin{array}{l}\text { (mini-ISY100)TAAATGAAGCG } \\
\text { TाTC (plus/minus) }\end{array}$ & SO_0266 & $\begin{array}{l}\text { Cytochrome c-type biogenesis } \\
\text { protein CcmF }\end{array}$ & 266,418 \\
\hline So_pale-3 & $\begin{array}{l}\text { (mini-ISY100)TAATACGCCCA } \\
\text { CCAAG (plus/minus) }\end{array}$ & SO_0266 & $\begin{array}{l}\text { Cytochrome c-type biogenesis } \\
\text { protein CcmF }\end{array}$ & 266,362 \\
\hline So_pale-4 & $\begin{array}{l}\text { (mini-ISY100)TATGGGCATGG } \\
\text { GCGTG (plus/minus) }\end{array}$ & SO_0696 & $\begin{array}{l}\text { Protein-disulfide reductase } \\
\text { DsbD }\end{array}$ & 714,906 \\
\hline
\end{tabular}

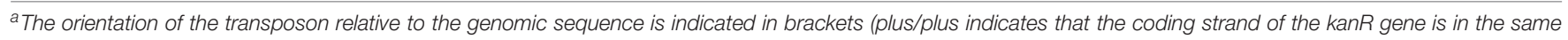
orientation as the reported genome sequence; plus/minus indicates they are in opposite directions). 
and pale colony color should be confirmed by complementation and/or gene knockout experiments.

\section{Delivery of a Genetic Cargo}

Next, we investigated the use of mini-ISY100 to deliver a genetic cargo to the genomes of different bacterial species. The sequence of pISY100mini was modified so that it could be used to deliver a chromosomal "landing pad" for ФC31 integrase-mediated cassette exchange (Fogg et al., 2014). ФC31 integrase catalyzes efficient unidirectional recombination between short DNA sites knows as attP and attB (Thorpe and Smith, 1998). A ФC31 att $B$ site with a TT central dinucleotide $\left(a t t B^{\mathrm{TT}}\right)$ together with the rpsL streptomycin sensitivity gene from $E$. coli was placed at one end of the mini-ISY100 just inside the left

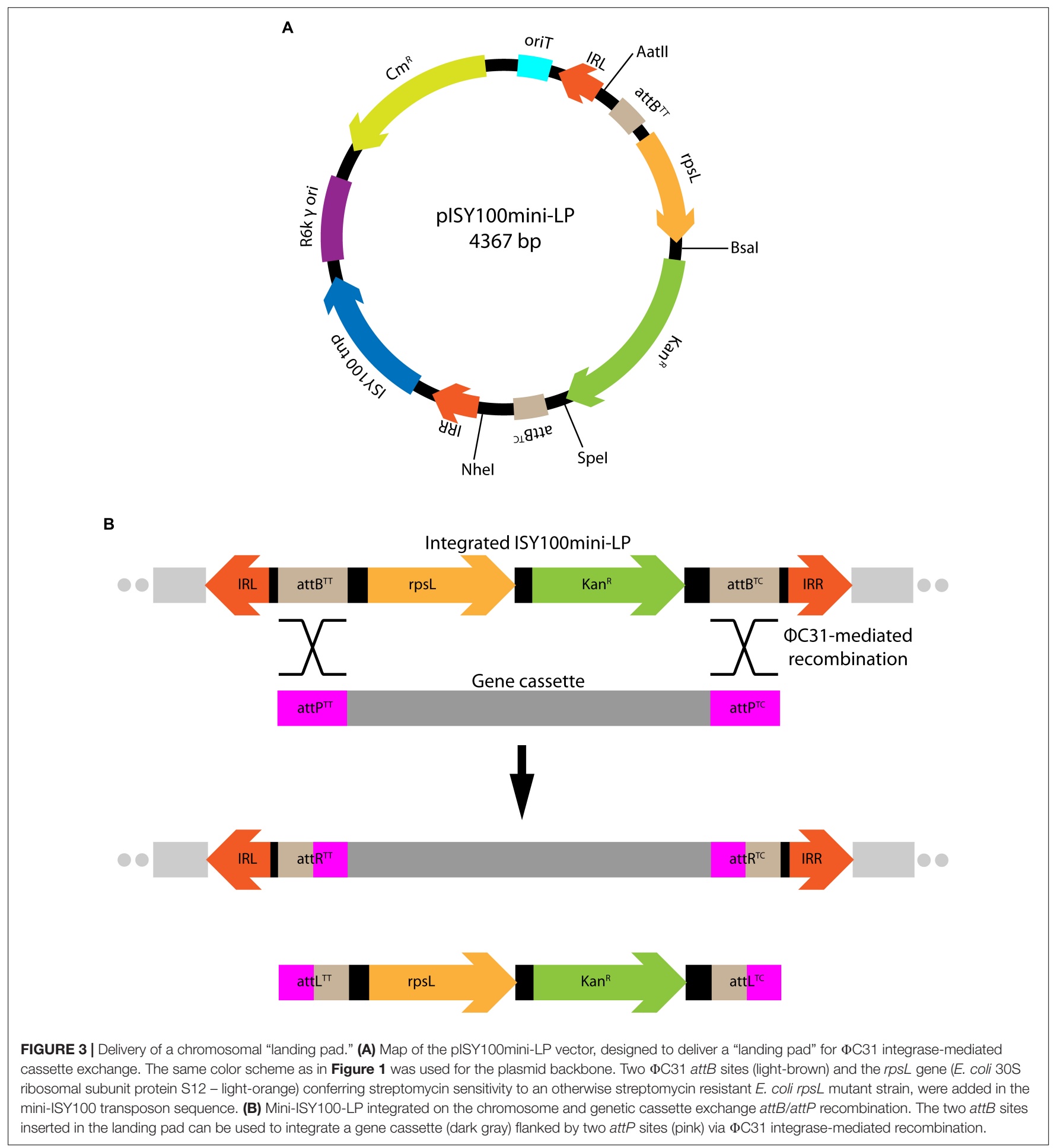


TABLE 6 | mini-ISY100-LP transposition frequency in different species.

\begin{tabular}{lcl}
\hline Strain & $\begin{array}{c}\text { Kan }^{\mathbf{R}} \\
\text { colonies/reaction }^{\mathbf{a}}\end{array}$ & Transposition frequency $^{\mathbf{b}}$ \\
\hline Escherichia coli MG1655 & $4.2 \times 10^{4}$ & $4.1 \times 10^{-5} \pm 9.20 \times 10^{-6}$ \\
Acinetobacter baumannii & $8.75 \times 10^{2}$ & $1.2 \times 10^{-6} \pm 6.4 \times 10^{-8}$ \\
Acinetobacter baylyi & $1.4 \times 10^{5}$ & $9.8 \times 10^{-5} \pm 3.0 \times 10^{-5}$ \\
Pseudomonas aeruginosa & $1.05 \times 10^{6}$ & $1.5 \times 10^{-3}$ \\
\hline
\end{tabular}

${ }^{a}$ Total number of $\mathrm{Kan}^{R}$ colonies obtained from a single plate mating between MFDpir and the indicated recipient bacteria, calculated from plating appropriate dilutions. ${ }^{b}$ Number of colonies on $L B / K a n$ divided by the number of colonies on $L B$.

inverted repeat, and $a t t B$ with a TC central dinucleotide $\left(a t t B^{\mathrm{TC}}\right)$ was placed at the other end, just inside IRR, creating pISY100mini-LP (Figure 3A). These changes add 684 bp to mini-ISY100, bringing the total size of the genetic cargo carried by mini-ISY100-LP to 1,679 bp. pISY100mini-LP can be delivered by conjugation as before, and transposon insertions can be selected using the kanamycin resistance gene. Once on the chromosome of a bacterial host, a genetic cassette flanked by attP $P^{\mathrm{TT}}$ and att $P^{\mathrm{TC}}$ recombination sites could be integrated into the landing pad using $\Phi C 31$ integrase-mediated recombination (Figure 3B; S. D. Colloms, unpublished results). This cassette exchange could be selected for by loss of the rpsL (Reyrat et al., 1998) or gain of a marker carried on the cassette.

The ability of this larger landing pad ISY100 to transpose was tested in the following bacteria: E. coli MG1655, A. baumannii ATCC19606, A. baylyi ADP1 and P. aeruginosa PAO1. MG1655 was used as a wild-type $E$. coli control. $P$. aeruginosa and $A$. baumannii are human pathogens of high clinical importance - both are listed within the top three species where urgent need for additional research is required (World Health
Organization, 2017). A. baylyi is a genetically tractable relative of $A$. baumannii. New genetic tools that work in these species could help identify genes required for their virulence and/or new drug targets.

MFDpir/pISY100mini-LP was used as a donor for conjugation. Conjugations were plated on LB to count recipient cells, $\mathrm{LB} \mathrm{Cm}$ to verify that the donor plasmid cannot replicate in the recipient strains, and LB Kan to determine the number of transposition events. No colonies were obtained on LB Cm plates, whereas hundreds ( $A$. baumannii) to over a million ( $P$. aeruginosa) kanamycin resistant colonies were obtained from the conjugations (Table 6). Using arbitrary PCR and DNA sequencing, the locations of transposon insertions were determined in three random kanamycin resistant colonies for each species. Insertions were in apparently random TA dinucleotides in the genomes of all species (Supplementary Table S2).

\section{DISCUSSION}

The use of transposons as tools for genetic engineering has recently undergone a large expansion. Here we describe the design and application of a new mini transposon insertion mutagenesis tool based on the ISY100 (ISTcSA) transposon from Synechocystis sp. PCC6803. In comparison with other members of the same mariner family, the advantages of the ISTcSA transposase are its small size (only 282 amino acids) and the possibility to be modified to specifically target precise sequences without a loss of functionality (Feng et al., 2010).

Like other members of the Tc1/mariner family, including Sleeping Beauty and Himar1, ISY100 inserts almost exclusively

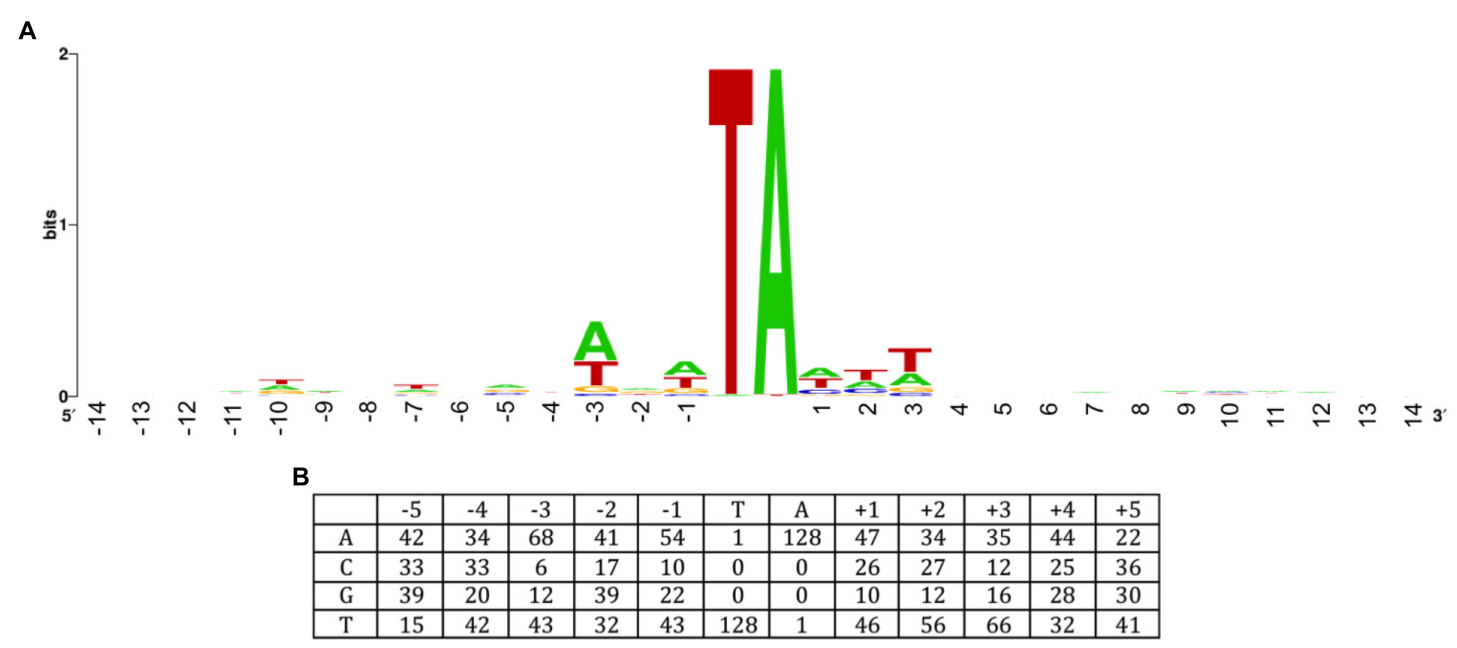

FIGURE 4 | ISY100 target site preference. The sequences of 21 ISY100 insertions in the Synechocystis PCC6803 genome, three in large Synechocystis plasmids, 19 insertions isolated in plasmid targets in E. coli, and 58 different insertion sites generated by in vivo and in vitro transposition into the target plasmid pH 2 were previously analyzed (Feng et al., 2010). The 28 insertions isolated in this work were added to this alignment and analyzed for conserved sequence features.

(A) WebLogo (Crooks et al., 2004) showing sequence information content 14 nucleotides on either side of the target TA. (B) Base frequencies 5 nucleotides on either side of the target TA. 
into TA dinucleotides. To see if there is any target site preference outside this TA, the sequences of 101 previously reported insertions sites (Feng et al., 2010) were combined with the 28 new insertion sites reported in this study (Figure 4). Analysis of these sequences suggests that there is a slight preference for insertion sites that are A/T-rich in the three nucleotides on either side of the TA target. This specificity differs from other transposases commonly used in prokaryotes, such as $\mathrm{Mu}\left\{5^{\prime} \mathrm{CPy}(\mathrm{G} / \mathrm{C}) \mathrm{PuG}\right\}$ or Tn5 $\left\{5^{\prime}\right.$ GPyPyPy(A/T)PuPuPuC\} (Green et al., 2012), but might be similar to other mariner transposons such as Sleeping Beauty $\left(5^{\prime}\right.$ ATATATAT) (Liu et al., 2005) and Himar1, where no consensus target sequence has been detected but sites with the sequence (C/G)GNTANC(C/G) have been found to be non-permissive for insertion (DeJesus et al., 2017).

The frequency of the mini-ISY100 transposition was shown to be affected by the method used to deliver the pISY100mini suicide plasmid to recipient cells. Conjugation was found to result in the most efficient transposition for all species tested and is thus our method of choice, as previously shown for other transposons (Christie-Oleza et al., 2009). Conjugation also represents the best technique to overcome the barriers to genetic exchange between different species, expanding the adaptability of our pISY100mini vector delivery system. Using the conjugation delivery system, we were able to obtain large libraries of knock-out mutants in seven different species of $\gamma$ proteobacteria, belonging to four different orders. These results show the lack of requirement of any specific co-factor for the transposition of the mini-ISY100 transposon and open the possibility of a successful application of the delivery system in other species.

We applied our protocol to create and characterize a miniISY100 knock-out library in S. oneidensis, screening the mutants for loss of colony color. The analysis of the mini-ISY100 insertion sites in the chromosome of the pale colored S. oneidensis colonies led to the putative identification of two genes involved in this phenotype, $c c m F$ and $d s b D$. While mutations in $c c m F$ were previously associated with the appearance of pale colonies on LB media (Fu et al., 2015), this is the first time such a phenotype is reported for a mutation in $d s b D$, proving the utility of our system. The fact that four, rare, pale colored colonies from a library of $\sim 12,000$ mutants all had different insertion sites, is

\section{REFERENCES}

Akerley, B. J., Rubin, E. J., Camilli, A., Lampe, D. J., Robertson, H. M., and Mekalanos, J. J. (1998). Systematic identification of essential genes by in vitro mariner mutagenesis. Proc. Natl. Acad. Sci. U.S.A. 95, 8927-8932. doi: 10.1073/ pnas.95.15.8927

Bachmann, B. J. (1996). "Derivations and genotypes of some mutant derivatives of Escherichia coli K-12," in Escherichia coli and Salmonella typhimurium Cellular and Molecular Biology, ed. F. C. Neidhardt (Washington, DC: ASM Press).

Bardarov, S., Kriakov, J., Carriere, C., Yu, S., Vaamonde, C., McAdam, R. A., et al. (1997). Conditionally replicating mycobacteriophages: a system for transposon delivery to Mycobacterium tuberculosis. Proc. Natl. Acad. Sci. U.S.A. 94, 1096110966. doi: 10.1073/pnas.94.20.10961

Baym, M., Shaket, L., Anzai, I. A., Adesina, O., and Barstow, B. (2016). Rapid construction of a whole-genome transposon insertion collection for convincing evidence that a large proportion of colonies in this S. oneidensis library were not siblings but came from independent insertion events.

We also created a modified version of the mini-ISY100 transposon, named mini-ISY100-LP, designed to deliver a landing pad in a random location of the host chromosome to allow the insertion of genetic cassettes mediated by the integrase from bacteriophage $\Phi C 31$. While the transposition frequency of the mini-ISY100-LP transposon in E. coli is reduced in comparison with the mini-ISY100 transposon, probably due to the presence of a larger genetic cargo, the efficiency of the system still yields large libraries of transposon insertions in all four species tested. We have yet to determine if there is an upper limit to the size of the genetic cargo.

The addition of ISY100 to our microbial genetic tool box complements existing transposon delivery systems and might facilitate development of new technologies that could for instance require orthogonal transposons, or different sequences in the inverted repeats. The high efficiency and the flexibility of pISY100mini should make it a valuable tool for genetic studies in a broad range of bacterial species.

\section{AUTHOR CONTRIBUTIONS}

EC, IG, and SC conceived and designed the work. EC, LM, and IG performed the experiments. EC drafted the manuscript. IG and SC critically revised the manuscript. All authors read and approved the final version of the article.

\section{FUNDING}

This work was funded by a Leverhulme Trust grant (RP2013$\mathrm{K}-017)$ to SC.

\section{SUPPLEMENTARY MATERIAL}

The Supplementary Material for this article can be found online at: https://www.frontiersin.org/articles/10.3389/fmicb. 2019.00280/full\#supplementary-material

Shewanella oneidensis by Knockout Sudoku. Nat. Commun. 7:13270. doi: 10 . $1038 /$ ncomms 13270

Beck, E., Ludwig, G., Auerswald, E. A., Reiss, B., and Schaller, H. (1982). Nucleotide sequence and exact localization of the neomycin phosphotransferase gene from transposon Tn5. Gene 19, 327-336. doi: 10.1016/0378-1119(82)90023-3

Bouhenni, R., Gehrke, A., and Saffarini, D. (2005). Identification of genes involved in cytochrome c biogenesis in Shewanella oneidensis, using a modified mariner transposon. Appl. Environ. Microbiol. 71, 4935-4937. doi: 10.1128/AEM.71.8. 4935-4937.2005

Bouvet, P. J., and Grimont, P. A. (1986). Taxonomy of the genus Acinetobacter with the recognition of Acinetobacter baumannii sp. nov., Acinetobacter haemolyticus sp. nov., Acinetobacter johnsonii sp. nov., and Acinetobacter junii sp. nov. and emended descriptions of Acinetobacter calcoaceticus and Acinetobacter lwoffii. Int. J. Syst. Bacteriol. 36, 228-240. doi: 10.1099/0020771336-2-228 
Cassier-Chauvat, C., Poncelet, M., and Chauvat, F. (1997). Three insertion sequences from the cyanobacterium Synechocystis PCC6803 support the occurrence of horizontal DNA transfer among bacteria. Gene 195, 257-266. doi: 10.1016/S0378-1119(97)00 $165-0$

Choi, K.-H., and Kim, K.-J. (2009). Applications of transposon-based gene delivery system in bacteria. J. Microbiol. Biotechnol. 19, 217-228. doi: 10.4014/jmb. 0811.669

Christie-Oleza, J. A., Lanfranconi, M. P., Nogales, B., Lalucat, J., and Bosch, R. (2009). Conjugative interaction induces transposition of ISPst9 in Pseudomonas stutzeri AN10. J. Bacteriol. 191, 1239-1247. doi: 10.1128/JB.01071-08

Crooks, G. E., Hon, G., Chandonia, J.-M., and Brenner, S. E. (2004). WebLogo: a sequence logo generator. Genome Res. 14, 1188-1190. doi: 10.1101/gr.849004

Das, S., Noe, J. C., Paik, S., and Kitten, T. (2005). An improved arbitrary primed PCR method for rapid characterization of transposon insertion sites. J. Microbiol. Methods 63, 89-94. doi: 10.1016/j.mimet.2005.02.011

DeJesus, M. A., Gerrick, E. R., Xu, W., Park, S. W., Long, J. E., Boutte, C. C., et al. (2017). Comprehensive essentiality analysis of the Mycobacterium tuberculosis genome via saturating transposon mutagenesis. mBio 8:e02133-16. doi: 10.1128/ mBio.02133-16

Demarre, G., Guérout, A.-M., Matsumoto-Mashimo, C., Rowe-Magnus, D. A., Marlière, P., and Mazel, D. (2005). A new family of mobilizable suicide plasmids based on broad host range R388 plasmid (IncW) and RP4 plasmid (IncP $\alpha$ ) conjugative machineries and their cognate Escherichia coli host strains. Res. Microbiol. 156, 245-255. doi: 10.1016/j.resmic.2004.09.007

Ding, Q., and Tan, K. S. (2017). Himarl transposon for efficient random mutagenesis in Aggregatibacter actinomycetemcomitans. Front. Microbiol. 8:1842. doi: 10.3389/fmicb.2017.01842

Ehrmann, M., Bolek, P., Mondigler, M., Boyd, D., and Lange, R. (1997). TnTIN and TnTAP: mini-transposons for site-specific proteolysis in vivo. Proc. Natl. Acad. Sci. U.S.A. 94, 13111-13115. doi: 10.1073/pnas.94.24.13111

Feng, X., Bednarz, A. L., and Colloms, S. D. (2010). Precise targeted integration by a chimaeric transposase zinc-finger fusion protein. Nucleic Acids Res. 38, 1204-1216. doi: 10.1093/nar/gkp1068

Feng, X., and Colloms, S. D. (2007). In vitro transposition of ISY100, a bacterial insertion sequence belonging to the Tc1/mariner family. Mol. Microbiol. 65, 1432-1443. doi: 10.1111/j.1365-2958.2007.05842.x

Ferrières, L., Hémery, G., Nham, T., Guérout, A.-M., Mazel, D., Beloin, C., et al. (2010). Silent mischief: bacteriophage $\mathrm{Mu}$ insertions contaminate products of Escherichia coli random mutagenesis performed using suicidal transposon delivery plasmids mobilized by broad-host-range RP4 conjugative machinery. J. Bacteriol. 192, 6418-6427. doi: 10.1128/JB.00621-10

Fogg, P. C. M., Colloms, S., Rosser, S., Stark, M., and Smith, M. C. M. (2014). New applications for phage integrases. J. Mol. Biol. 426, 2703-2716. doi: 10.1016/j. jmb.2014.05.014

Fraser, M. J., Ciszczon, T., Elick, T., and Bauser, C. (1996). Precise excision of TTAA-specific lepidopteran transposons piggyBac (IFP2) and tagalong (TFP3) from the baculovirus genome in cell lines from two species of Lepidoptera. Insect Mol. Biol. 5, 141-151. doi: 10.1111/j.1365-2583.1996. tb00048.x

Fredrickson, J. K., Romine, M. F., Beliaev, A. S., Auchtung, J. M., Driscoll, M. E., Gardner, T. S., et al. (2008). Towards environmental systems biology of Shewanella. Nat. Rev. Microbiol. 6, 592-603. doi: 10.1038/nrmicro 1947

Freed, N. E., Bumann, D., and Silander, O. K. (2016). Combining Shigella Tnseq data with gold-standard E. coli gene deletion data suggests rare transitions between essential and non-essential gene functionality. BMC Microbiol. 16:203. doi: 10.1186/s12866-016-0818-0

Fu, H., Jin, M., Wan, F., and Gao, H. (2015). Shewanella oneidensis cytochrome $c$ maturation component $\mathrm{CcmI}$ is essential for heme attachment at the noncanonical motif of nitrite reductase NrfA. Mol. Microbiol. 95, 410-425. doi: $10.1111 / \mathrm{mmi} .12865$

Gallagher, L. A., Ramage, E., Patrapuvich, R., Weiss, E., Brittnacher, M., and Manoil, C. (2013). Sequence-defined transposon mutant library of Burkholderia thailandensis. mBio 4:e00604-13. doi: 10.1128/mBio.00604-13

Gao, F., Luo, H., Zhang, C.-T., and Zhang, R. (2015). Gene essentiality analysis based on DEG 10, an updated database of essential genes. Methods Mol. Biol. Clifton NJ 1279, 219-233. doi: 10.1007/978-1-4939-2398-4_14
Glass, J. I., Assad-Garcia, N., Alperovich, N., Yooseph, S., Lewis, M. R., Maruf, M., et al. (2006). Essential genes of a minimal bacterium. Proc. Natl. Acad. Sci. U.S.A. 103, 425-430. doi: 10.1073/pnas.0510013103

Grant, S. G., Jessee, J., Bloom, F. R., and Hanahan, D. (1990). Differential plasmid rescue from transgenic mouse DNAs into Escherichia coli methylationrestriction mutants. Proc. Natl. Acad. Sci. U.S.A. 87, 4645-4649. doi: 10.1073/ pnas.87.12.4645

Green, B., Bouchier, C., Fairhead, C., Craig, N. L., and Cormack, B. P. (2012). Insertion site preference of $\mathrm{Mu}, \mathrm{Tn} 5$, and Tn7 transposons. Mob. DNA 3:3. doi: 10.1186/1759-8753-3-3

Hara, Y., Kadotani, N., Izui, H., Katashkina, J. I., Kuvaeva, T. M., Andreeva, I. G., et al. (2012). The complete genome sequence of Pantoea ananatis AJ13355, an organism with great biotechnological potential. Appl. Microbiol. Biotechnol. 93, 331-341. doi: 10.1007/s00253-011-3713-5

Holloway, B. (1975). Genetic organization of Pseudomonas, in: Genetics and Biochemistry of Pseudomonas. London: John Wiley \& Sons Ltd, 133-161.

Hughes, K. T. (2007). Generation of deletions and duplications using transposons as portable regions of homology with emphasis on mud and Tn10 transposons. Methods Enzymol. 421, 51-68. doi: 10.1016/S0076-6879(06)21007-3

Jacobs, M. A., Alwood, A., Thaipisuttikul, I., Spencer, D., Haugen, E., Ernst, S., et al. (2003). Comprehensive transposon mutant library of Pseudomonas aeruginosa. Proc. Natl. Acad. Sci. U.S.A. 100, 14339-14344. doi: 10.1073/pnas.203628 2100

Kimura, S., Hubbard, T. P., Davis, B. M., and Waldor, M. K. (2016). The nucleoid binding protein $\mathrm{H}-\mathrm{NS}$ biases genome-wide transposon insertion landscapes. mBio 7:e01351-16. doi: 10.1128/mBio.01351-16

Liberati, N. T., Urbach, J. M., Miyata, S., Lee, D. G., Drenkard, E., Wu, G., et al. (2006). An ordered, nonredundant library of Pseudomonas aeruginosa strain PA14 transposon insertion mutants. Proc. Natl. Acad. Sci. U.S.A. 103, 2833-2838. doi: 10.1073/pnas.0511100103

Liu, G., Geurts, A. M., Yae, K., Srinivasan, A. R., Fahrenkrug, S. C., Largaespada, D. A., et al. (2005). Target-site preferences of Sleeping Beauty transposons. J. Mol. Biol. 346, 161-173. doi: 10.1016/j.jmb.2004. 09.086

Metzgar, D., Bacher, J. M., Pezo, V., Reader, J., Döring, V., Schimmel, P., et al. (2004). Acinetobacter sp. ADP1: an ideal model organism for genetic analysis and genome engineering. Nucleic Acids Res. 32, 5780-5790. doi: 10.1093/nar/ gkh881

Nesmelova, I. V., and Hackett, P. B. (2010). DDE transposases: structural similarity and diversity. Adv. Drug Deliv. Rev. 62, 1187-1195. doi: 10.1016/j.addr.2010. 06.006

Ni, J., Clark, K. J., Fahrenkrug, S. C., and Ekker, S. C. (2008). Transposon tools hopping in vertebrates. Brief. Funct. Genomic. Proteomic. 7, 444-453. doi: 10. 1093/bfgp/eln049

Olins, P. O., and Rangwala, S. H. (1989). A novel sequence element derived from bacteriophage T7 mRNA acts as an enhancer of translation of the lac $Z$ gene in Escherichia coli. J. Biol. Chem. 264, 16973-16976.

Picardeau, M. (2010). Transposition of fly mariner elements into bacteria as a genetic tool for mutagenesis. Genetica 138, 551-558. doi: 10.1007/s10709-0099408-5

Rainey, P. B., and Bailey, M. J. (1996). Physical and genetic map of the Pseudomonas fluorescens SBW25 chromosome. Mol. Microbiol. 19, 521-533. doi: 10.1046/j. 1365-2958.1996.391926.x

Reyrat, J. M., Pelicic, V., Gicquel, B., and Rappuoli, R. (1998). Counterselectable markers: untapped tools for bacterial genetics and pathogenesis. Infect. Immun. 66, 4011-4017.

Rollefson, J. B., Levar, C. E., and Bond, D. R. (2009). Identification of genes involved in biofilm formation and respiration via mini-Himar transposon mutagenesis of Geobacter sulfurreducens. J. Bacteriol. 191, 4207-4217. doi: 10.1128/JB. 00057-09

Rubin, E. J., Akerley, B. J., Novik, V. N., Lampe, D. J., Husson, R. N., and Mekalanos, J. J. (1999). In vivo transposition of mariner-based elements in enteric bacteria and mycobacteria. Proc. Natl. Acad. Sci. U.S.A. 96, 1645-1650. doi: 10.1073/pnas.96.4.1645

Sambrook, J. F., and Russell, D. W. (2001). Molecular Cloning: a Laboratory Manual, 3rd Edn. Cold Spring Harbor: NYCSH Laboratory Press.

Silby, M. W., Cerdeño-Tárraga, A. M., Vernikos, G. S., Giddens, S. R., Jackson, R. W., Preston, G. M., et al. (2009). Genomic and genetic analyses of diversity 
and plant interactions of Pseudomonas fluorescens. Genome Biol. 10:R51. doi: 10.1186/gb-2009-10-5-r51

Suganuma, R., Pelczar, P., Spetz, J. F., Hohn, B., Yanagimachi, R., and Moisyadi, S. (2005). Tn5 transposase-mediated mouse transgenesis. Biol. Reprod. 73, 11571163. doi: 10.1095/biolreprod.105.044669

Taylor, L. A., and Rose, R. E. (1988). A correction in the nucleotide sequence of the Tn903 kanamycin resistance determinant in pUC4K. Nucleic Acids Res. 16:358. doi: 10.1093/nar/16.1.358

Taylor, R. G., Walker, D. C., and McInnes, R. R. (1993). E. coli host strains significantly affect the quality of small scale plasmid DNA preparations used for sequencing. Nucleic Acids Res. 21, 1677-1678. doi: 10.1093/nar/21.7.1677

Thorpe, H. M., and Smith, M. C. (1998). In vitro site-specific integration of bacteriophage DNA catalyzed by a recombinase of the resolvase/invertase family. Proc. Natl. Acad. Sci. U.S.A. 95, 5505-5510. doi: 10.1073/pnas.95.10. 5505

Urasaki, A., Sekine, Y., and Ohtsubo, E. (2002). Transposition of cyanobacterium insertion element ISY100 in Escherichia coli. J. Bacteriol. 184, 5104-5112. doi: 10.1128/JB.184.18.5104-5112.2002

van Opijnen, T., and Camilli, A. (2013). Transposon insertion sequencing: a new tool for systems-level analysis of microorganisms. Nat. Rev. Microbiol. 11, 435-442. doi: 10.1038/nrmicro3033

Venkateswaran, K., Moser, D. P., Dollhopf, M. E., Lies, D. P., Saffarini, D. A., MacGregor, B. J., et al. (1999). Polyphasic taxonomy of the genus Shewanella and description of Shewanella oneidensis sp. nov.
Int. J. Syst. Bacteriol. 49(Pt 2), 705-724. doi: 10.1099/00207713-49$2-705$

Verissimo, A. F., and Daldal, F. (2014). Cytochrome $c$ biogenesis System I: an intricate process catalyzed by a maturase supercomplex? Biochim. Biophys. Acta 1837, 989-998. doi: 10.1016/j.bbabio.2014. 03.003

Wolkow, C. A., DeBoy, R. T., and Craig, N. L. (1996). Conjugating plasmids are preferred targets for Tn7. Genes Dev. 10, 2145-2157. doi: 10.1101/gad.10.17. 2145

World Health Organization (2017). Global Priority List of Antibiotic-Resistant Bacteria to Guide Research, Discovery, and Development of New Antibiotics. Available at: http://www.who.int/medicines/publications/global-priority-listantibiotic-resistant-bacteria/en/

Conflict of Interest Statement: The authors declare that the research was conducted in the absence of any commercial or financial relationships that could be construed as a potential conflict of interest.

Copyright (C) 2019 Conte, Mende, Grainge and Colloms. This is an open-access article distributed under the terms of the Creative Commons Attribution License (CC BY). The use, distribution or reproduction in other forums is permitted, provided the original author(s) and the copyright owner(s) are credited and that the original publication in this journal is cited, in accordance with accepted academic practice. No use, distribution or reproduction is permitted which does not comply with these terms. 